\title{
Полянська Алла,
}

доктор економічних наук, професор,

Івано-Франківський національний технічний університет нафти $і$ газу,

Інститут економіки і управління у нафтогазовому комплексі

\section{ПРИНЦИПИ МІЖНАРОДНОГО ПАРТНЕРСТВА В РОЗВИТКУ ВІТЧИЗНЯНИХ ПІДПРИЕМСТВ}

У статті досліджено сутність, характеристику та роль міжнародного партнерства у розвитку вітчизняних підприємств в умовах глобалізації, особлива увага приділена формуванню партнерських відносин у газовій галузі. Узагальнено принципи міжнародного партнерства на національному та міжнародному рівнях. Визначено значимість принципів міжнародного підприємства в розвитку газової галузі та на основі проведенного оцінювання досвіду розвитку партнерських відносин у галузі виділено напрями діяльності, які на сьогодні характеризують результативність міжнародного співробітництва у галузі. Проведені дослідження дозволяють обґрунтувати напрями зміцнення та розширення потенціалу міжнародної співпраці на основі застосування розглянутих принципів міжнародного партнерства.

Ключові слова: міжнародне партнерство; принципи; газова галузь; логістичний ланцюг; глобалізація.

(C) Polyanska Alla

Надійшла до редакції 14.04.2017

УДК 332.122-043.86(477)

УСИК ІГОР,

здобувач, Донещький нац̧інальний університет імені Василя Стуса, м. Вінниия

\section{ТЕНДЕНЦІї ЕКОНОМІЧНОГО РОЗВИТКУ ТЕРИТОРІЙ УКРАЇНИ}

У статті визначено сучасний стан економічного розвитку територій України. Розглянуто валовий регіональний продукт, який є узагальнювальним показником економічної діяльності, результативності та характеризує новостворену вартість товарів і послуг, вироблених на певній території. Наведено географічну структуру розподілу валового регіонального продукту та виявлено його відмінності по регіонах України. Досліджено провідні області щодо виробництва найбільшої частки валового регіонального продукту. Проаналізовано види економічної діяльності деяких регіонів, виявлено динаміку зміни величини валового регіонального продукту в розрахунку на одну особу. Запропоновано напрямки збільшення валового регіонального продукту територій України, що забезпечить нові можливості та вигоди для областей та регіонів держави.

Ключові слова: регіони України; економічна діяльність; розвиток; господарство; показник; валовий регіональний продукт; динаміка; галузь; регіони; область.

Постановка проблеми. В умовах теперішніх змін світового господарства ключовими стають можливості створення дієвих механізмів вступу України в міжнародний політичний та економічний простір на основі використання регіональних моделей співробітництва. Стратегічною метою реалізації державної політики повинно бути створення умов для динамічного, збалансованого розвитку регіонів України з метою підвищення рівня їх конкурентоспроможності, активізації економічної діяльності, покращення рівня життя населення, забезпечення соціальних та економічних стандартів.

На сьогодні важливою передумовою забезпечення сталого зростання економіки, підвищення ефективності використання ресурсів $€$ об'єктивне визначення рівня розвитку регіонального потенціалу.

Аналіз останніх досліджень і публікацій. Дослідженням основних проблем в області регіонального розвитку займаються вітчизняні та закордонні автори, зокрема О. Амоша [9], П. Гальчинський та Б. Данилишин [7], Ю. Зайцева [6], Ю. Макогон [9], М. Павловський [8], Ю. Стадницький [10], М. Чумаченко [9], О. Шаблій, М. М. Якубовський [5], Cameron C. Gordon [3], Hendrik Van den Berg [12], A. Pyka, J. Foster [13], Karen L. Higgins [14] та інші. Вони розглядають стратегічні питання розвитку територій у контексті сучасних умов господарювання, напрями й механізми їх вирішення, норматив- 
но-правову базу, пропонують методи аналізу. Поважаючи розробки відомих учених, зазначимо, що потребують уточнення питання визначення сучасних тенденцій економічного розвитку регіонів для збалансованості національної економіки України.

Метою статті $є$ дослідження динаміки валового регіонального продукту деяких територій України для обґрунтування пріоритетних напрямків розвитку.

Виклад основного матеріалу. Важливими чинниками, що обумовлюють поточний стан соціально-економічного розвитку, є макро- та мікроекономічні. У масштабах країни для визначення результатів економічної діяльності використовується показник валового внутрішнього продукту (ВВП). На регіональному рівні узагальнювальним показником, який характеризує рівень розвитку економіки, є валовий регіональний продукт (ВРП). Методологічні принципи його формування були розроблені Р. Стоуном у 50-х роках XX століття. ВРП вимірюється вартістю товарів та послуг, виготовлених суб'єктами території для кінцевого використання. Це інтегрований показник економічного розвитку регіону, який характеризує внесок у створення валового внутрішнього продукту України. Розрахунки ВРП ґрунтуються на міжнародних стандартах "Система національних рахунків 2008" та "Європейська система національних і регіональних рахунків 2010" [1]. Огляд літературних джерел свідчить, що в цей час регіональні рахунки використовуються в багатьох країнах світу [2, 4].

При розрахунку ВРП використовується "виробничий метод". При цьому основними показниками $є$ випуск, проміжне споживання, валова додана вартість, податки та субсидії на продукти [1]. Субсидії на продукти - це вид субсидій, які надаються пропорційно кількості або вартості продуктів та послуг, реалізованих на внутрішньому ринку або експортованих резидентом. Вони включають відшкодування з державного та місцевих бюджетів підприємствам у порядку державного регулювання цін на сільськогосподарську та іншу продукцію. Другий різновид таких субсидій призначається для покриття поточних збитків підприємств (житлово-комунального господарства, установ культури тощо), поліпшення їх фінансового становища шляхом поповнення оборотних коштів або компенсації окремих витрат [Там само].

Перевага ВРП полягає в тому, що за його допомогою можна не тільки оцінювати розвиток конкретної області, але й проводити об'єктивне порівняння ступеня розвитку різних регіонів країни. Основною його рисою $€$ те, що він відображає в грошовому вираженні кінцеві результати діяльності підприємств і організацій, які поділяються за видами економічної діяльності, інституційними секторами економіки, та обмежує обчислення цих результатів певною територією.

Серед видів економічної діяльності виділяють дві великі групи галузей, які забезпечують створення валового регіонального продукту. До однієї відносяться ті, що виготовляють товари. Найважливішими серед них $€$ промисловість, сільське та лісове господарство, будівництво, а також інші види діяльності з виробництва товарів.

До іншої належать галузі, які надають послуги. До їх переліку входять транспорт та зв'язок, торгівля, харчування, наукова та технічна діяльність, охорона здоров'я, освіта, державне управління тощо.

За даними Державної служби статистики, найбільша частка валового регіонального продукту у ВВП України протягом 2005-2015 рр. спостерігається в м. Києві - від 17,2 до 22,7 \% (табл. 1) [1]. Серед областей вирізняються Донецька, Дніпропетровська та Харківська. За цей період вони сумарно сорормували від 23 \% до $30 \%$ ВВП держави. Тобто лідерами економічного розвитку в Україні є промислові області.

Таблиця 1. - Частка валового регіонального продукту по областях України, \%

\begin{tabular}{|c|c|c|c|c|c|c|c|c|c|c|c|}
\hline & 2005 & 2006 & 2007 & 2008 & 2009 & 2010 & 2011 & 2012 & 2013 & 2014 & 2015 \\
\hline Україна & 100 & 100 & 100 & 100 & 100 & 100 & 100 & 100 & 100 & 100 & 100 \\
\hline $\begin{array}{l}\text { Автономна } \\
\text { Республіка Крим }\end{array}$ & 2,9 & 3,0 & 2,9 & 2,9 & 3,0 & 3,0 & 2,9 & 3,1 & 3,0 & - & - \\
\hline Вінницька & 2,3 & 2,3 & 2,1 & 2,1 & 2,2 & 2,2 & 2,2 & 2,3 & 2,4 & 2,8 & 3,0 \\
\hline Волинська & 1,5 & 1,4 & 1,4 & 1,3 & 1,3 & 1,3 & 1,4 & 1,4 & 1,4 & 1,5 & 1,6 \\
\hline Дніпропетровська & 9,3 & 9,6 & 9,9 & 11,0 & 10,2 & 10,7 & 10,8 & 10,1 & 10,0 & 11,1 & 10,8 \\
\hline Донецька & 13,1 & 13,3 & 12,8 & 12,4 & 11,4 & 11,9 & 12,4 & 11,7 & 10,8 & 7,6 & 5,8 \\
\hline Житомирська & 1,7 & 1,6 & 1,5 & 1,6 & 1,6 & 1,7 & 1,7 & 1,7 & 1,7 & 1,9 & 1,9 \\
\hline Закарпатська & 1,5 & 1,5 & 1,5 & 1,4 & 1,4 & 1,4 & 1,4 & 1,5 & 1,4 & 1,5 & 1,5 \\
\hline Запорізька & 4,5 & 4,6 & 4,6 & 4,5 & 4,1 & 3,9 & 3,8 & 3,8 & 3,6 & 4,2 & 4,5 \\
\hline Івано-Франківська & 2,2 & 2,1 & 1,9 & 1,9 & 1,9 & 1,9 & 2,1 & 2,2 & 2,2 & 2,4 & 2,3 \\
\hline Київська & 3,5 & 3,5 & 3,6 & 3,8 & 4,1 & 4,2 & 4,5 & 4,8 & 4,5 & 5,0 & 5,2 \\
\hline Кіровоградська & 1,6 & 1,5 & 1,4 & 1,5 & 1,5 & 1,5 & 1,5 & 1,5 & 1,7 & 1,8 & 1,9 \\
\hline Луганська & 4,5 & 4,4 & 4,5 & 4,5 & 4,2 & 4,2 & 4,4 & 4,0 & 3,6 & 2,0 & 1,2 \\
\hline Львівська & 3,9 & 3,9 & 3,9 & 3,7 & 3,9 & 3,8 & 4,0 & 4,3 & 4,2 & 4,6 & 4,8 \\
\hline Миколаївська & 2,2 & 2,2 & 2,0 & 2,0 & 2,2 & 2,2 & 2,1 & 2,0 & 2,1 & 2,2 & 2,4 \\
\hline Одеська & 4,7 & 4,6 & 4,6 & 5,0 & 5,3 & 5,0 & 4,7 & 4,4 & 4,6 & 4,7 & 5,0 \\
\hline Полтавська & 4,1 & 4,1 & 3,9 & 3,6 & 3,7 & 4,1 & 4,0 & 3,9 & 3,8 & 4,4 & 4,8 \\
\hline Рівненська & 1,6 & 1,6 & 1,6 & 1,5 & 1,5 & 1,5 & 1,5 & 1,5 & 1,4 & 1,8 & 1,8 \\
\hline Сумська & 1,8 & 1,8 & 1,7 & 1,7 & 1,8 & 1,7 & 1,8 & 1,7 & 1,8 & 1,9 & 2,1 \\
\hline Тернопільська & 1,2 & 1,2 & 1,1 & 1,1 & 1,2 & 1,2 & 1,2 & 1,2 & 1,2 & 1,4 & 1,3 \\
\hline Харківська & 5,8 & 5,9 & 6,1 & 6,3 & 6,5 & 6,0 & 5,9 & 5,6 & 5,6 & 6,1 & 6,3 \\
\hline Херсонська & 1,5 & 1,4 & 1,3 & 1,4 & 1,5 & 1,4 & 1,4 & 1,3 & 1,4 & 1,5 & 1,6 \\
\hline Хмельницька & 1,8 & 1,8 & 1,7 & 1,7 & 1,7 & 1,7 & 1,8 & 1,8 & 1,7 & 2,0 & 2,1 \\
\hline Черкаська & 2,0 & 2,0 & 1,9 & 2,0 & 2,0 & 2,1 & 2,1 & 2,1 & 2,2 & 2,4 & 2,6 \\
\hline Чернівецька & 1,0 & 0,9 & 0,9 & 0,9 & 0,9 & 0,9 & 0,9 & 0,9 & 0,9 & 0,9 & 0,9 \\
\hline Чернігівська & 1,7 & 1,6 & 1,6 & 1,6 & 1,6 & 1,6 & 1,6 & 1,6 & 1,6 & 1,8 & 1,9 \\
\hline М. Київ & 17,5 & 17,5 & 18,9 & 17,9 & 18,6 & 18,2 & 17,2 & 18,9 & 20,5 & 22,5 & 22,7 \\
\hline м. Севастополь & 0,6 & 0,7 & 0,7 & 0,7 & 0,7 & 0,7 & 0,7 & 0,7 & 0,7 & - & - \\
\hline
\end{tabular}


Як бачимо з таблиці, динаміка ВРП протягом періоду дослідження залишалася переважно позитивною. Темпи зростання валового регіонального продукту свідчать, що розвиток України характеризується тенденціями економічного зростання більшості областей країни.

Проведемо аналіз зміни ВРП по регіонах, серед яких умовно визначимо п'ять - Північну, Південну, Західну, Східну та Центральну Україну. Північна включає Житомирську, Київську, Сумську і Чернігівську області. Південна - це Автономна Республіка Крим, Одеська, Миколаївська і Херсонська області. Західна охоплює вісім адміністративних областей - Львівську, Івано-Франківську, Закарпатську, Тернопільську, Рівненську, Хмельницьку, Волинську та Чернівецьку. Східна - найбільш індустріально розвинений і густонаселений регіон, який включає Харківську, Донецьку, Луганську і Запорізьку області. Центральну представляють Вінницька, Кіровоградська, Черкаська, Полтавська і Дніпропетровська області.

На підставі аналізу даних за 2005-2015 роки можна зробити висновок про такий розподіл валового регіонального продукту: у Північному регіоні перше місце посідає Київська область, у Південному - Одеська, Західному - лідером $є$ Львівська, Східному - Донецька, а в Центральному - Дніпропетровська. Однак серед цих областей-лідерів рівень ВРП коливається від 3,6 до $12,8 \%$ (рис. 1) [1].

Валовий регіональний продукт, як і валовий внутрішній продукт, характеризує кінцевий результат виробничої діяльності підприємств та організацій. Ці показники відображають вартість товарів і послуг, вироблених протягом звітного періоду в цінах покупця. Отже, вони орієнтують населення і господарюючі суб'єкти на випуск не будь-якої продукції та надання послуг, а винятково таких, які користуються платоспроможним попитом.

Виходячи з такого економічного розуміння ВРП, проблема його зростання дійсно $€$ найважливішою для керівників регіонів. У збільшенні ВРП закладений успіх розвитку країни, суспільства, підвищення матеріального достатку окремої людини.

За результатами обробки статистичних даних було визначено, за рахунок яких видів економічної діяльності лідирують п'ять областей у регіонах України (рис. 2) [11].

У Київській області 31,6 \% становлять підприємства

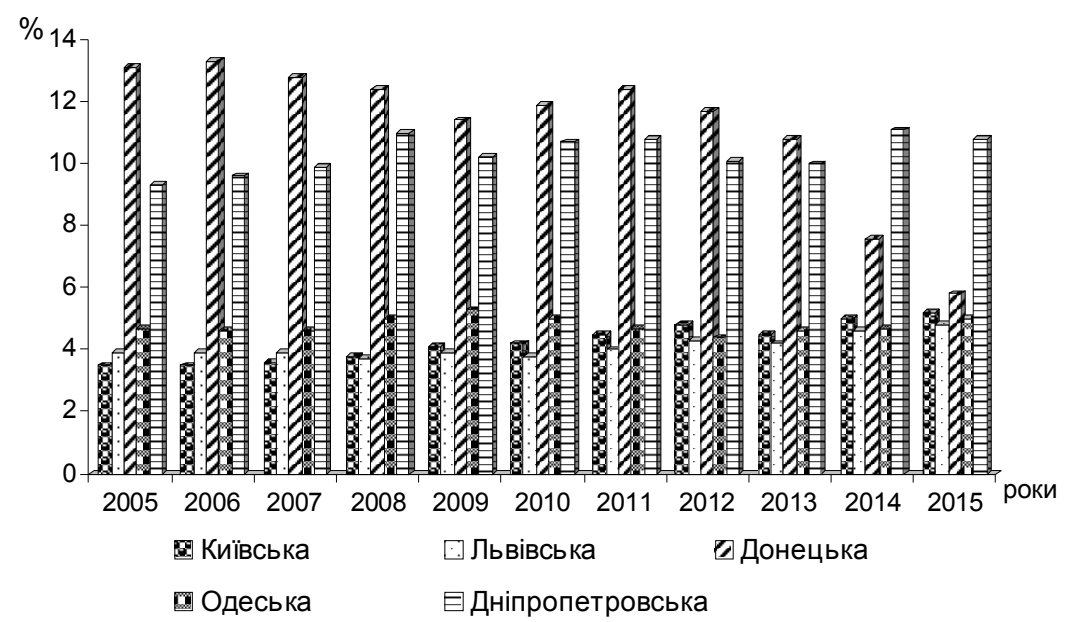

Рис. 1. Частка виробництва валового регіонального продукту в провідних областях України, \%.

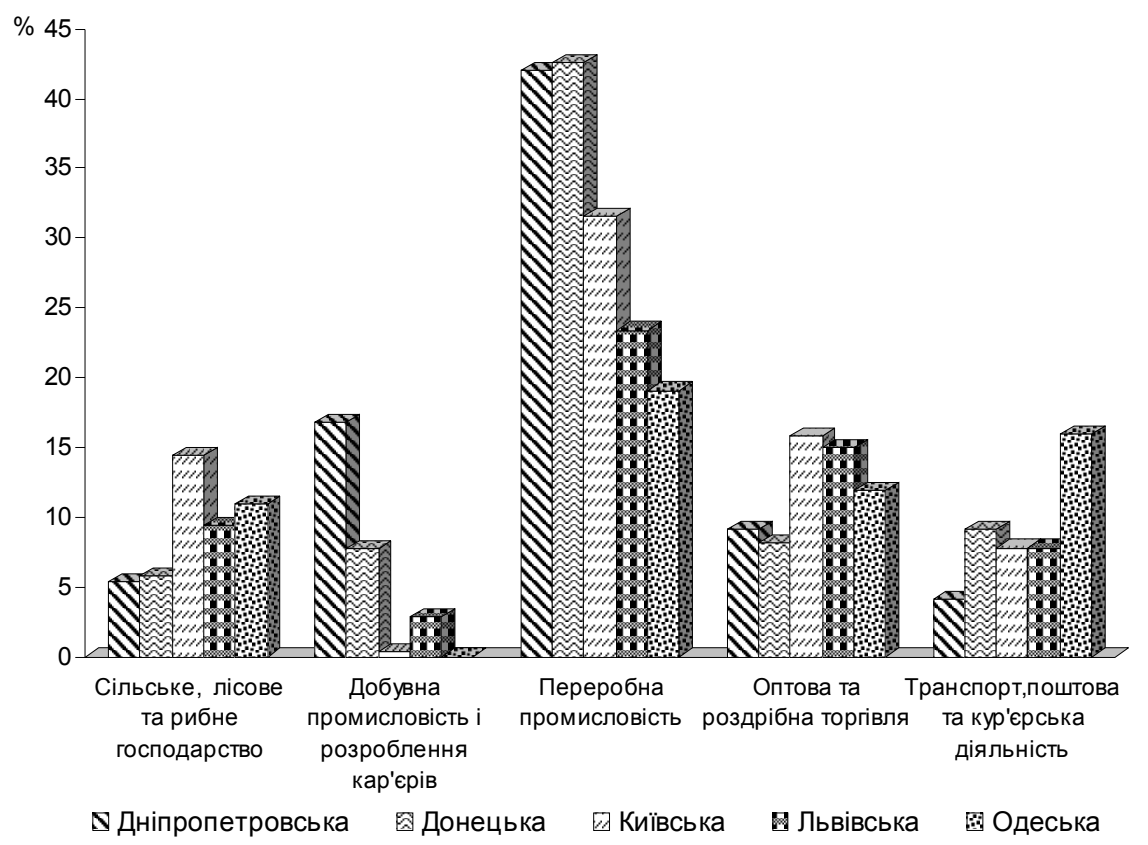

Рис. 2. Структура видів економічної діяльності деяких областей України. 
переробної промисловості; 15,8 \% - оптової та роздрібної торгівлі; 14,4 \% - сільського, лісового та рибного господарства [11].

В Одеській області має місце такий поділ - 19,1\% підприємств переробної промисловості; 16,0% - транспорт, складське господарство, поштова та кур'єрська діяльність; 11,9 \% - оптова та роздрібна торгівля [Там само]

У Львівській області спостерігається аналогічна структура: 23,4 \% підприємств переробної промисловості; 15,0 \% - оптової та роздрібної торгівлі; 9,4 \% сільського, лісового та рибного господарства [Там само].

У Дніпропетровській області основне місце належить переробній промисловості - 42,0 \%; добувній - 16,8 \%, оптової та роздрібної торгівлі - 9,1 \% [Там само].

У Донецькій області на першому місці переробна промисловість - 42,6 \%; на другому - транспорт, складське господарство, поштова та кур'єрська діяльність - 9,1 \% на третьому - оптова та роздрібна торгівля - 8,1 \% [11].

Усі ці області об'єднує те, що велику частку займають підприємства переробної промисловості, а також оптової та роздрібної торгівлі. Сільське, лісове, рибне господарство та торгівля найбільш розвинені в Київській області, добувна промисловість - у Дніпропетровській, переробна - у Донецькій, а складське господарство, поштова, транспортна та кур'єрська діяльність - в Одеській області.

У сучасних умовах на першому місці за питомою вагою в цих областях, знаходяться галузі виробництва. На них припадає близько половини виробництва валового регіонального продукту, тобто їх загальна частка залишається досить високою. При цьому відсоток галузей, які надають послуги, залишається незначним.

На сучасному етапі економічного розвитку в провідних в економічному відношенні областях України посилилась промислово-виробнича складова, у зв'язку з власними ресурсами й можливостями. Орієнтуючись на них, регіональні органи влади шукають способи підйому рівня економічного розвитку.
У цілому по Україні структура випуску за видами економічної діяльності складається так: переробна промисловість - 29,1\%, оптова та роздрібна торгівля - 13,2 \%, сільське, лісове та рибне господарство $11,4 \%[11]$

Зростаючими галузями у світі $€$ мікроелектроніка, комунікації і зв'язок, генна інженерія, біотехнології, інформатика, сорера послуг тощо, тому важливими позитивними напрямками для розвитку регіонів України $\epsilon$ істотне збільшення частки торгівлі й громадського харчування, інформаційно-телекомунікаційного обслуговування, операцій із нерухомим майном, промисловості, охорони здоров'я та надання соціальної допомоги. Ці перспективні зміни сприятимуть підвищенню ВРП в економіці областей, створенню необхідної інфраструктури, зниженню рівня безробіття.

У процесі виявлення позитивних або негативних тенденцій зміни величини валового регіонального продукту важливе місце займає його розрахунок на одну особу. Цей показник більшою мірою відображає динаміку ділової активності, що розгортається в області.

За допомогою статистичних даних досліджено динаміку змін ВРП у розрахунку на одну особу по Україні. У фрактичних цінах цей показник збільшився з 9372 грн у 2005 р. до 46413 грн у 2015 р., тобто в 5 разів [1]. Отже, величина ВРП на душу населення в цілому по країні постійно збільшується.

У розрахунку на одну особу найбільші показники валового регіонального продукту за 2005-2015 рр. зафіксовано в м. Києві, Дніпропетровській, Донецькій та Полтавській областях. На жаль, основним фактором цього зростання являються інфляційні процеси.

Аналіз статистичних даних за період 2005-2015 рр. свідчить, що найчастіше найбільший ВРП у розрахунку на одну особу вироблявся в регіонах України таким чином: Північний - Київська область, Південний - Одеська, Західний - Львівська, Східний - Донецька, Центральний - Дніпропетровська (табл. 2) [1].

Таблиця 2. - Валовий регіональний продукт у розрахунку на одну особу (грн)

\begin{tabular}{|l|c|c|c|c|c|c|c|c|}
\hline & $\mathbf{2 0 0 5}$ & $\mathbf{2 0 0 9}$ & $\mathbf{2 0 1 0}$ & $\mathbf{2 0 1 1}$ & $\mathbf{2 0 1 2}$ & $\mathbf{2 0 1 3}$ & $\mathbf{2 0 1 4}$ & 2015 \\
\hline Україна & $\mathbf{9 3 7 2}$ & $\mathbf{1 9 8 3 2}$ & $\mathbf{2 3 6 0 0}$ & $\mathbf{2 8 4 8 8}$ & $\mathbf{3 2 0 0 2}$ & $\mathbf{3 3 4 7 3}$ & $\mathbf{3 6 9 0 4}$ & $\mathbf{4 6 4 1 3}$ \\
\hline Північна & & & & & & & & \\
\hline Житомирська & 5554 & 11419 & 14616 & 17184 & 19551 & 20286 & 23678 & 30698 \\
\hline Київська & 8673 & 21769 & 26140 & 34420 & 40483 & 39988 & 46058 & 60109 \\
\hline Сумська & 6497 & 13631 & 15711 & 19800 & 21722 & 23517 & 26943 & 37170 \\
\hline Чернігівська & 6474 & 13121 & 15406 & 19357 & 22096 & 22603 & 26530 & 35196 \\
\hline Південна & & & & & & & & \\
\hline $\begin{array}{l}\text { Автономна } \\
\text { Республіка Крим }\end{array}$ & 6460 & 13933 & 16507 & 19467 & 22675 & 23595 & - & \\
\hline Миколаївська & 7801 & 17050 & 20276 & 23402 & 24838 & 27355 & 30357 & 41501 \\
\hline Одеська & 8619 & 20341 & 22544 & 25748 & 27070 & 29118 & 31268 & 41682 \\
\hline Херсонська & 5713 & 12256 & 14346 & 16990 & 17910 & 19311 & 21725 & 30246 \\
\hline Західна & & & & & & & & \\
\hline Івано-Франківська & 6916 & 12485 & 14814 & 19386 & 23379 & 24022 & 27232 & 33170 \\
\hline Львівська & 6657 & 14093 & 16353 & 20490 & 24387 & 24937 & 28731 & 37338 \\
\hline Закарпатська & 5373 & 10081 & 12278 & 14455 & 17088 & 17044 & 19170 & 22989 \\
\hline Тернопільська & 4603 & 10240 & 11713 & 15055 & 16644 & 16819 & 20228 & 24963 \\
\hline Рівненська & 6269 & 11699 & 13785 & 16735 & 18860 & 19003 & 24762 & 30350 \\
\hline Волинська & 6285 & 11796 & 13916 & 16993 & 19249 & 19817 & 23218 & 30387 \\
\hline Хмельнццька & 5764 & 11780 & 13602 & 17260 & 19920 & 20165 & 24662 & 31660 \\
\hline Чернівецька & 4654 & 9383 & 10939 & 13228 & 14529 & 15154 & 16552 & 20338 \\
\hline Східна & & & & & & & & \\
\hline Донецька & 12490 & 23137 & 28986 & 36446 & 38907 & 37830 & 27771 & 26864 \\
\hline Харківська & 9025 & 21228 & 23639 & 27966 & 29972 & 31128 & 35328 & 45816 \\
\hline
\end{tabular}


Продовження табл. 2

\begin{tabular}{|l|c|c|c|c|c|c|c|c|}
\hline & 2005 & 2009 & 2010 & 2011 & 2012 & 2013 & 2014 & 2015 \\
\hline Запорізька & 10683 & 20614 & 23657 & 27567 & 30656 & 30526 & 37251 & 50609 \\
\hline Луганська & 8131 & 16562 & 19788 & 25067 & 25950 & 24514 & 14079 & 10778 \\
\hline Центральна & & & & & & & & \\
\hline Вінницька & 5966 & 12145 & 14332 & 17768 & 20253 & 22303 & 27249 & 37270 \\
\hline Кіровоградська & 6394 & 13096 & 15533 & 19918 & 22082 & 25533 & 29223 & 39356 \\
\hline Дніпропетровська & 11909 & 27737 & 34709 & 42068 & 44650 & 46333 & 53749 & 65897 \\
\hline Полтавська & 11574 & 22337 & 29652 & 35246 & 38424 & 39962 & 48040 & 66390 \\
\hline Черкаська & 6681 & 14393 & 17325 & 21082 & 24558 & 26168 & 30628 & 40759 \\
\hline
\end{tabular}

Динаміка змін валового регіонального продукту на одну особу в Україні (без урахування Києва) ілюструє триразову відмінність між максимальним та мінімальним значеннями. Це свідчить про значну нерівномірність розвитку регіонів.

\section{Висновки}

Валовий регіональний продукт є важливим показником економічного стану областей, регіонів і країни в цілому. Дослідження свідчать, що протягом 20052015 рр. найбільша частка валового регіонального продукту вироблялася в м. Києві та промислових областях України - Дніпропетровській, Донецькій та Харківській. Темпи зростання ВРП на більшості територій позитивні.

Серед регіонів України спостерігається велика частка галузей, які виготовляють товари, це, зокрема, переробна, добувна промисловість, а сфера послуг займає невеликий відсоток.

За результатами проведеного аналізу можна стверджувати, що зміни структури ВРП та тенденції розвитку територій можуть полягати в нарощуванні частки галузей промисловості та сфери послуг. Необхідність таких перетворень пов'язана зі створенням оптимальної ринкової інфраструктури, науково-технічним прогресом, розвитком банківської діяльності, страхуванням, проведенням операцій із нерухомим майном, реструктуризацією виробництва, виготовленням тих товарів і послуг, які орієнтовані на різноманітний попит населення як за ціновими параметрами, так і за якісними характеристиками.

\section{ЛІТЕРАТУРА}

1. Валовой региональный продукт (2004-2015) [Електронний ресурс]. - Режим доступу : http://www.ukrstat.gov.ua/

2. Верланов О. Ю. Фактори формування валового регіонального продукту [Електронний ресурс] / О. Ю. Верланов // Наукові праці. - 2014. - Т. 126. - Вип. 113. - С. 113. - Режим доступу : http://lib.chdu.edu.ua/pdf/naukpraci/economy.
3. Cameron G. C. Regional Economic Development: The Federal Role examines the economic viability of depressed areas and regions / Gordon C. Cameron. - Taylor\&Francis, 2015. DOI: 10.4324/ 9781315671680

4. Грицяк І. Моделі регіонального та місцевого рівнів європейського управління / І. Грицяк // Проблеми децентралізації: національний та міжнародний досвід. - К. : Атіка, 2016. - C. 269-279.

5. Державне регулювання економіки України: методологія, напрями, тенденції, проблеми / [за ред. М. М. Якубовського]. - К. : НДЕІ Міністерства економіки України, 2015. - 410 с.

6. Зайцева Ю. Валовой региональный продукт. Структурный анализ и межрегиональные сопоставления / Ю. Зайцева. - LAP LAMBERT Academic Publishing, 2011. - 400 c.

7. Невелєв О. М. Сталий розвиток регіону: стратегічні напрями і механізми / О. М. Невелєв, Б. М. Данилишин. - К. : Логос, 2013. - 127 c.

8. Павловський М. Макроекономіка перехідного періоду. Український контекст / М. Павловський. - К. : Техніка, 2015. $336 \mathrm{c}$.

9. Регулювання регіонального розвитку в Україні [Електронний ресурс] / О. І. Амоша, Ю. В. Макогон, М. Г. Чумаченко. - Режим доступу : https://scholar.google.com.ua/citations?view_ $\mathrm{op}=\mathrm{view}$ _citation\&hl=ru\&user=SI_DzOAAAAAJ\&citation_for_view $=$ SI_DzOAAAAAJ:geHnlv5EZngC.

10. Стадницький Ю. І. Просторовий чинник конкуренції технологій виробництва продукції / Ю.І.Стадницький // Pегіональна економіка. - 2016. - № 4. - С. 130-136.

11. Статистичний збірник "Регіони України" [Електронний ресурс] / Державна служба статистики України. - 2016. - Режим доступу : http://www.ukrstat.gov.ua/

12. Van den Berg Hendrik. Economic Growth and Development (3 edition) / Hendrik van den Berg. - World Scientific, 2016. $924 \mathrm{p}$.

13. Pyka A. The Evolution of Economic and Innovation Systems I A. Pyka, J. Foster. - Economic Complexity and Evolution, Springer International Publishing Switzerland, 2015. DOI: 10.1007\%2F9783-319-13299-0_1.

14. Higgins L. Karen Economic Growth and Sustainability / Karen L. Higgin. - Elsevier Science Publishing Co Inc, 2014. $228 \mathrm{p}$.

\author{
Усик Игорь, \\ соискатель, \\ Донецүкий нацииональный университет имени Васыля Стуса, г. Винницуа
}

\title{
ТЕНДЕНЦИИ ЭКОНОМИЧЕСКОГО РАЗВИТИЯ ТЕРРИТОРИЙ УКРАИНЫ
}

В статье определено современное состояние экономического развития территорий Украины. Рассмотрен валовый региональный продукт, представляющий собой обобщающий показатель экономической результативности и характеризующий новосозданную стоимость товаров и услуг, произведенных на определенной территории. Приведена географическая структура распределения валового регионального продукта и выявлены его отличия в регионах Украины. Исследованы ведущие области страны, в которых производится наибольшая доля валового регионального продукта. Проанализированы виды экономической деятельности некоторых регионов, выявлена динамика изменения величины валового регионального продукта в расче- 
те на одного жителя. Предложены направления увеличения валового регионального продукта территорий Украины, что обеспечит новые возможности и выгоды для областей и регионов страны.

Ключевые слова: регионы Украины; экономическая деятельность; развитие; хозяйство; показатель; валовой региональный продукт; динамика; отрасль; регионы; область.

Usik Igor,

competitor

Vasyl Stus Donetsk National University, Vinnitsa

\section{TRENDS IN ECONOMIC DEVELOPMENT OF THE REGIONS UKRAINE}

The article defines the current state of economic development the territories of Ukraine. Important factors that determine it are macro- and microeconomic. On a national scale, the indicator of gross domestic product is used to determine the results of economic activity. At the regional level, a gross regional product is a general indicator characterizing the level of development the economy. It represents a general indicator of economic activity, performance and characterizes the newly created value of goods and services produced in a certain territory. The geographical structure of the distribution of the gross regional product is presented and its differences are revealed in the regions, among which five are determined: North, South, West, East and Central Ukraine. The leading regions in which the largest share of the gross regional product is produced are investigated. The types of economic activity of some regions are analyzed. It is determined that in today's conditions the industries producing goods are in first place in terms of their relative density. They account for about half of the gross regional product. At the same time, the percentage of industries providing services remains insignificant. The dynamics of the change in the value of the gross regional product per one inhabitant was revealed. It illustrates the threefold difference between the maximum and minimum value in Ukraine. This indicates a significant uneven development of the regions. The directions for increasing the gross regional product are proposed, which consist in increasing the share of industries and services. The need for such reforms is related to the creation of an optimal market infrastructure, scientific and technological progress, the development of banking, insurance, real estate transactions, the restructuring of production, the production of those goods and services that are aimed at the broad demand of the population both in price parameters and quality characteristics.

Key words: regions of Ukraine; economic activity; development; agriculture; indicator; gross regional product; dynamics; industry; region; area.

\section{REFERENCES}

1. Gross regional product (2004-2015), available at: http://www.ukrstat.gov.ua/

2. Verlanov, O. (2014), Factors formation GRP, Coll. works. Vol. 126 - Vol. 113, p. 113, available at: http://lib.chdu.edu.ua/pdf/ naukpraci/ economy (ukr).

3. Cameron, G. C. (2015), Regional Economic Development: The Federal Role examines the economic viability of depressed areas and regions Taylor\&Francis, DOI: 10.4324/9781315671680.

4. Hrytsiak, I. (2016), Models regional and local levels of European governance , in: Problems of decentralization: national and international experience, Atika Publishing, Kyiv, 269-279 (ukr).

5. Jakubowski, M.M. [Ed.] (2015), State regulation of Economy of Ukraine: Methodology, directions, trends and issues, NDEI Ministry of Economy of Ukraine, Kyiv, 410 p. (ukr).

6. Zaitseva, Yu. (2011), Gross regional product. Structural analysis and interregional comparisons, LAP LAMBERT Academic Publishing, 400 p. (rus).

7. Nevelyev, O.M. \& Danylyshyn, B.M. (2013), Sustainable development of the region, strategic directions and mechanisms, Logos, Kyiv, 127 p. (ukr).

8. Pawlowski, M. (2015), Macroeconomics transition. Ukrainian context, Engineering, Kyiv, 336 p. (ukr).

9. Amosha, O.I. \& Makogon, Y. V. \& Chumachenko, M.G. and all (2006), Regional development in Ukraine, Economika promyslovosti, №2 (33), available at: https://scholar.google.com.ua/citations?view_op=view_citationother\&hl=ru\&user=SI_DzOAAAAAJ\&citation_ for_view=SI_DzOAAAAAJ:geHnlv5EZngC

10. Stadnytskyy, Y.I. (2016), Spatial competition factor of production technology, Regional Economics, № 4, 130-136 (ukr).

11. Statistical Yearbook "Regions of Ukraine» (2016), State Statistics Service of Ukraine, available at: http://www.ukrstat.gov.ua/

12. Van den Berg, Hendrik (2016), Economic Growth and Development (3 edition), World Scientific, 924 p. (eng).

13. Pyka, A. \& Foster, J. (2015), The Evolution of Economic and Innovation Systems, in: Economic Complexity and Evolution, DOI: 10.1007\%2F978-3-319-13299-0 1.

14. Higgins, L. Karen (2014), Economic Growth and Sustainability, Elsevier Science Publishing Co Inc, $228 \mathrm{p}$.

(C) Усик Іаор

Надійшла до редакції 10.04.2017 